DOI: $10.2478 / \mathrm{v} 10025-008-0002-5$

JOURNAL OF WATER

AND LAND DEVELOPMENT

J. Water Land Dev. No. 11, 2007: 17-30

\title{
Economic incentives in land reclamation sector in Lithuania
}

\author{
Antanas MAZILIAUSKAS ${ }^{1)}$, Vytautas MORKUNAS ${ }^{2)}$, \\ Zenonas RIMKUS ${ }^{3)}$, Valentinas $\breve{S} A U L Y S^{4)}$
}

1) Lithuanian University of Agriculture, e-mail: Antanas.Maziliauskas@nora.lzua.lt

${ }^{2)}$ Water Management Institute of Lithuanian University of Agriculture, e-mail: v.morkunas@water. omnitel.net

3) Lithuanian University of Agriculture, e-mail: zenonas@hidro.lzuu.lt

4) Water Management Institute of Lithuanian University of Agriculture, e-mail: valentinas@water. omnitel.net

\begin{abstract}
The study presents the critical evaluation of existing drainage systems from legal, economical, environmental and technical viewpoints. Nearly $80 \%$ of agricultural land in Lithuania drained by underground drainage systems covers around 3 million hectares. The prevailing large scale drainage systems with a complex of engineering structures such as conducting ditches, drains and collectors, local roads, bridges or farm road-crossings, dikes, dams, water reservoirs, pumping stations for irrigation and for drainage need today an efficient management solution in a new economic situation. The detailed analysis of legal and economic instruments adopted in transferring the management responsibilities of drainage systems to users has been carried out. The study resulted in a number of practical contributions towards the amendments in the Law on Land Reclamation in Lithuania and the establishment of a system of indicators that would allow rationalisation of subsidy allocations for the maintenance and improvement of the drainage systems. These subsidies from the state budget make at the moment the largest share among the investment sources. The financial and in kind contribution of drainage users is permanently increasing as are the allocations of the structural funds for public projects. The EU pre-accession programme SAPARD started in 2000 has supported some investments in rural areas. Unfortunately, it did not support the drainage infrastructure properly. A critical review of previous measures allowed suggesting new actions within the framework of the actual support from EU structural funds.
\end{abstract}

Key words: drainage systems, economic incentives, investment, management

\section{INTRODUCTION}

During the period since the declaration of the independence of Lithuania in 1991 large-scale reforms in all sectors of economy were going on. The reforms in land reclamation sector with drainage systems of 3 million hectares and large num- 
ber of different structures were necessary as well. The main problems to be solved were the preparation and implementation of new principles of management, repair and rehabilitation of the existing drainage systems and construction of the new ones. The land reclamation sector is one of those fields where the implementation of new methods and means for water management in rural areas was rather complicated and problematic.

The main reason is that the drainage systems were basically adapted to the large farms developing intensive agriculture based on land reclamation. Such policy was dominating in all regions of Lithuania, even in those, where the agricultural value of land was not very high. The drainage was installed not only in agricultural lands (arable soils, pastures), but also in some newly established areas, like wetlands, bushy lands, less valued forests, etc. About 200 thousand ha of wetlands from more then 480 thousand ha of total wetlands in Lithuania were transformed into an agricultural land after wetlands have been reclaimed. In few cases it exerted some negative impact on ecosystems.

All those investment activities of the former period resulted in a large number of drained areas and numerous engineering infrastructures (Tab. 1).

Table 1. The main data on drained land and structures as of 01.01.1994

\begin{tabular}{|c|c|c|}
\hline Indexes & Measure & Amount \\
\hline Total area of drained land & thousand ha & 3041 \\
\hline of which: drained by subsurface drainage & thousand ha & 2616 \\
\hline drained agricultural land & thousand ha & 2597 \\
\hline polder systems & thousand ha & 49 \\
\hline Area of irrigation systems & thousand ha & 17 \\
\hline Ditches & $\mathrm{km}$ & 62994 \\
\hline Subsurface drainage & thousand $\mathrm{km}$ & 1600 \\
\hline of which: collectors & thousand ha & 267 \\
\hline lateral drains & thousand ha & 1333 \\
\hline Bridges & piece & 1635 \\
\hline Farm road-crossings & piece & 65058 \\
\hline Pumping stations & piece & 261 \\
\hline of which: for drainage & piece & 111 \\
\hline for irrigation & piece & 150 \\
\hline Dams & $\mathrm{km}$ & 528 \\
\hline Structures on subsurface drainage network & thousand pieces & 710 \\
\hline of which: outlets & thousand pieces & 560 \\
\hline inverted drainage wells & thousand pieces & 139 \\
\hline dumb wells & thousand pieces & 11 \\
\hline Roads & $\mathrm{km}$ & 15712 \\
\hline Ponds/total area & piece $\cdot h^{-1}$ & $138 / 8197$ \\
\hline
\end{tabular}


Everything that was constructed during more then four decades belonged to the state. Under the new economical conditions such situation was not acceptable. The authorities responsible for water management sector addressed researchers to analyse the situation and to prepare proposals for the new legal documents how to solve the problem of the ownership between the state and farmers, how to organize management of drainage systems, from what sources the different works might be financed.

\section{MATERIALS AND METHODS}

The research was conducted in recent years at the Lithuanian University of Agriculture and Water Management Institute of the Lithuanian University of Agriculture. It has provided a real input for the preparation of national documents preparing the basis for the use of investment support for the rural sector by European and national funds.

The methodology of the study is based on a holistic approach incorporating a systematic assessment of all needs and opportunities for water management within the regular rural development support priorities. The research objective is to assess systematically how the integrated development strategy should create opportunities for the water management restructuring in terms of investment support.

The study was carried out by analysing the data of the Lithuanian Department of Statistics, State Institute of Land Management, Lithuanian Institute of Agrarian Economics, Ministry of Environment and Ministry of Agriculture. The legal documents of foreign countries and Lithuania in this field were studied as well.

\section{RESULTS AND DISCUSSIONS}

\section{PREPARATION OF THE LEGAL BASE}

Two principal elements must be taken into consideration when analysing the situation in land reclamation sector: the complexity of land reclamation works and the size of drainage or irrigation systems.

The set of works comprised the removal of stones and vegetation, arrangement of drainage or irrigation systems, smoothing and tillage of plots, construction of local roads, bridges or farm road-crossing, dikes, pumping stations for irrigation and for drainage, etc. Everything constructed was the state property and the state took care about it.

In order to create conditions for the optimal use of agricultural technique large plots of land were formed. The situation for the implementation of such idea was favourable enough: only one state farm was the landowner of few thousand hec- 
tares, financial resources and technical support were secured. This determined the arrangement of subsurface drainage up to few hundreds of hectares. Parameters of drainage water receivers were large: the depth of open ditches reached several meters, the diameter of subsurface collectors was up to one meter.

At the beginning of 2004 the Parliament of the Republic of Lithuania approved the new Land Reclamation Law. The way to this event was long and complicated. The main problem was to prepare the principles for distributing the ownership in land reclamation sector between the state and landowners. After prolonged debates among scientists, politicians and farmers a political decision was made - the network of subsurface drainage regulating soil water regime was transferred to landowners, the subsurface drainage water collectors with the diameter of $12.5 \mathrm{~cm}$ and larger were left for the state. Main ditches and polder systems were left for the state (local municipalities) as well.

Now farmers must take care of drainage systems on their own land. They are not left alone and may ask for a help from the state if they are able to defray the expenses no less than $15 \%$ (Valstybės..., 2004).

The new law is only a start for organization of land drainage management system. First of all it must be defined how to join farmers for combined management of the new property. Previously, there was one large drainage system; now there are several owners of the same system. Besides, the financial sources for construction, reconstruction and repair of drainage systems must be worked out and approved in legal acts.

\section{THE PRINCIPLES OF STATE GRANT DISTRIBUTION FOR DIFFERENT AGRICULTURAL REGIONS}

According to the new Land Reclamation Law, the state is partly responsible for the drainage systems. The state grant given for the maintenance of such systems must be distributed for the administrative districts.

According to studies on the costs of drainage systems maintenance, the optimal amount per year is $50-55 \mathrm{Lt}^{-} \mathrm{ha}^{-1}$ for ditches and 26-36 Lt $\cdot \mathrm{ha}^{-1}$ for repair of subsurface drainage. Total amount of money per one drained hectare is 76-87 Lt. In the last few years the state subsidies have constantly been $45 \mathrm{mln}$. Lt. It means that the state is able to cover only $20-25 \%$ of the needs (Fig. 1). (BUOŽIS and BASTINE, 1998). After implementation of the new law this amount may reach 30-35\%. In the case of financial shortage the state subsidies must be only used for most necessary works.

In order to prepare the principles of distribution of this support, the analyses of main factors having direct influence on sponsorship amount for every district were analysed. 


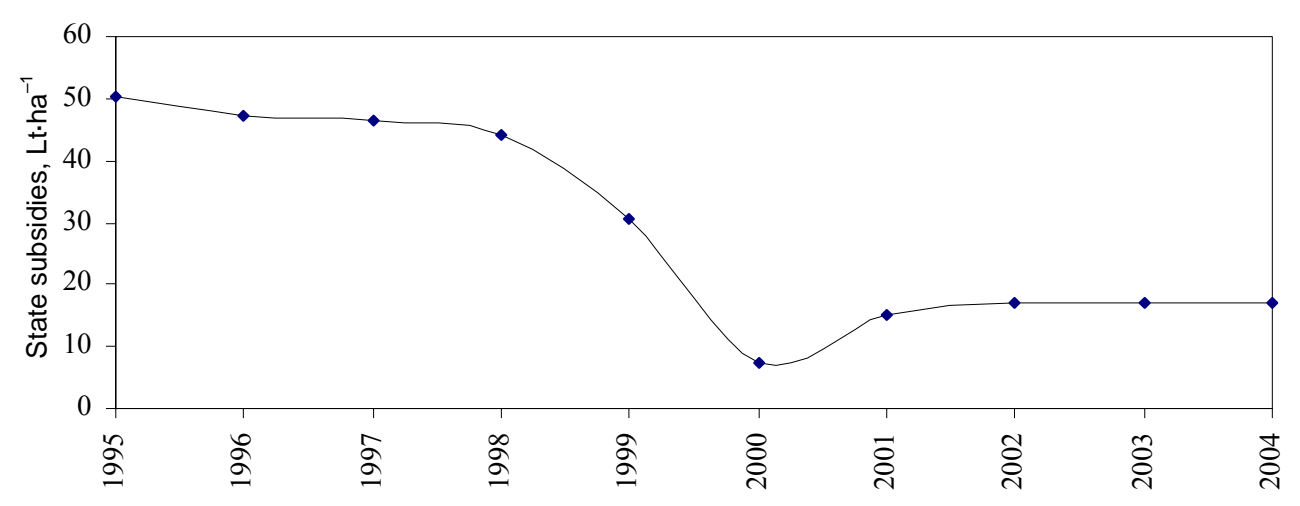

Fig. 1. State subsidies for the land reclamation sector

Lithuania is a small country with varying geographical factors. Plain areas with fertile soils dominate in the middle part of the country. In the south-east and in some places of western part the hilly relief and less fertile soils are prevailing.

According to similar conditions (in respect to relief) for drainage system maintenance the administrative districts are divided into three groups (Fig. 2). The first group comprises flat plots with intensive farming; here the conditions for drainage system maintenance are good. The third group includes hilly territories where maintenance conditions are complicated. The conditions of the second group are average comparing to the first and third groups. Some hilly plots and poor soils can be found there. Hydrogeological conditions are more difficult in the third and partly in the second group.

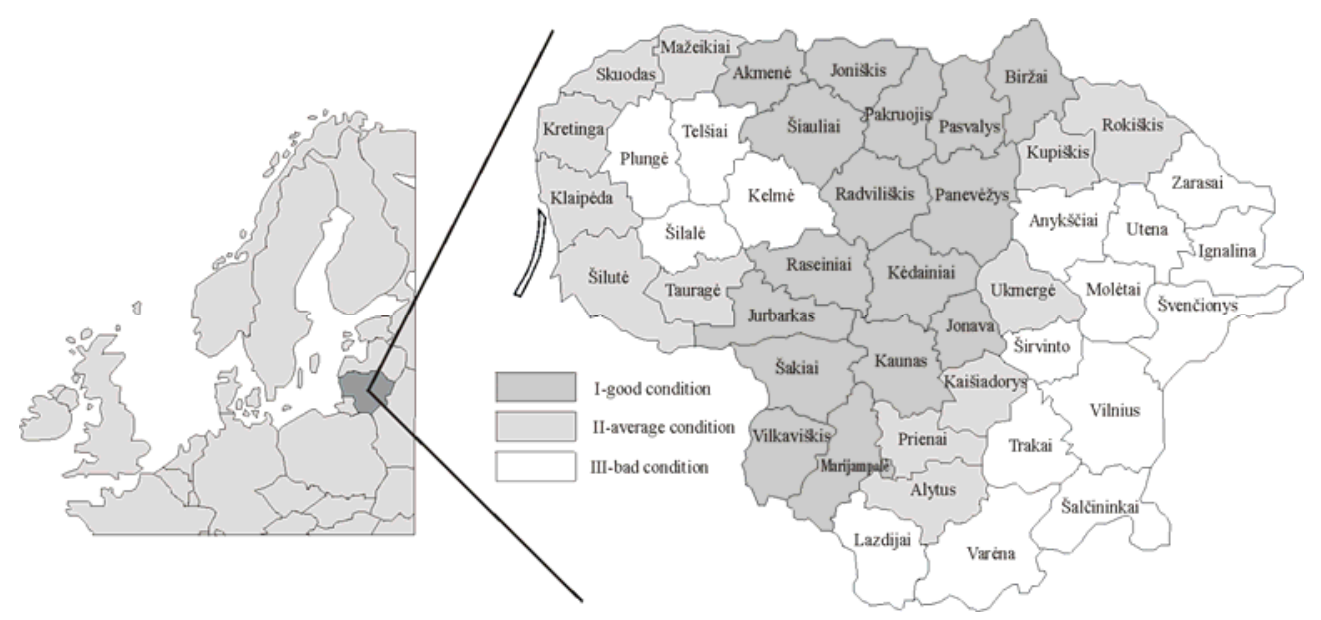

Fig. 2. The distribution of administrative districts to the groups of similar conditions for drainage system maintenance 
From the economical point of view the effectiveness of land drainage depends much on soil physical and chemical properties (Fig. 3).

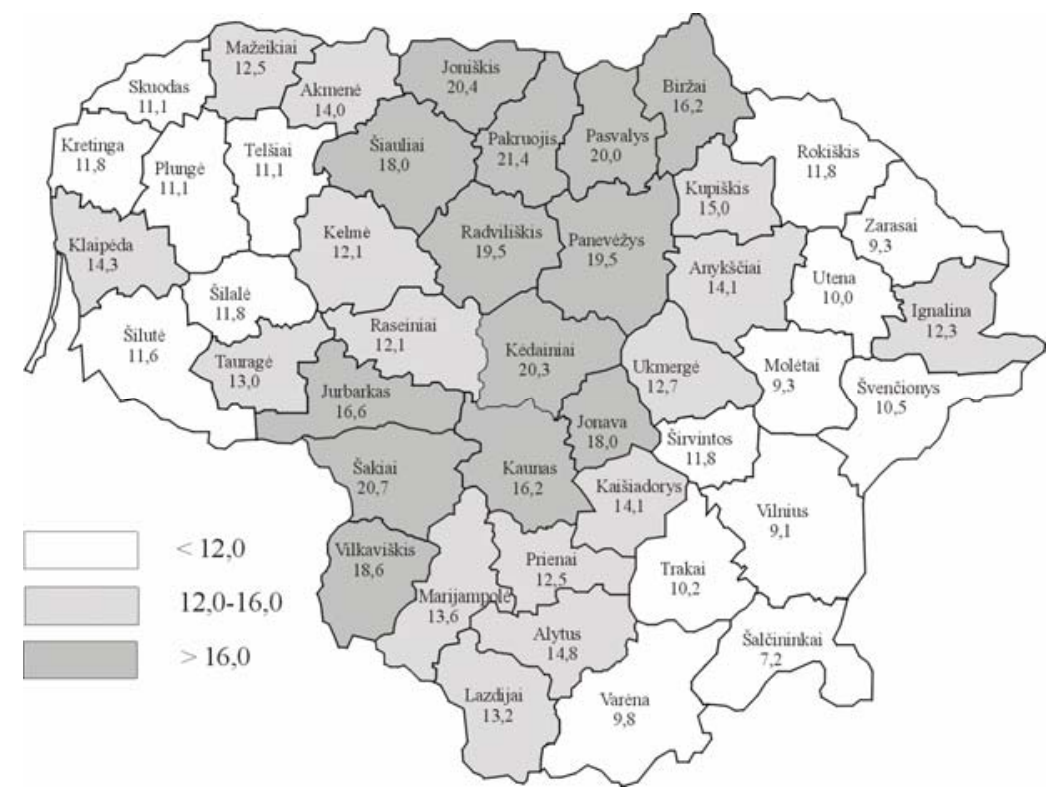

Fig. 3. Increase of agricultural land productivity in points due to drainage in various districts of Lithuania

The numbers on the map show how much the productivity of the land increased in points after land reclamation. The least significant influence on land productivity was found in the districts where the sandy soil or hills are dominant (Fig. 3 ). The agricultural productivity was lowest in the south-eastern part and highest in the middle. In such situation it is obvious that the investments must go to districts where the profit is highest. The farming practice has shown that agricultural activity in poor natural conditions is loss-making. The situation is understandable, if one remembers that the land reclamation in such districts some time ago was carried out without the real economical assessment.

The analysis of land use shows that under low income on poor soils and in places where the agricultural practice is not profitable the plots of unused drained land have increased (Lietuvos..., 2002). The plots of unexploited agricultural lands occupy $0.2-0.8 \%$ in districts of the middle part and up to $14.1-17.9 \%$ in the eastern part of the country.

The study results from the middle part of the country show that the area of unexploited lands depends on soil productivity (on points of soil productivity B) (BRUSOKAITĖ-STRAVINSKIENĖ, 2002): 


$$
A=5182.5 \mathrm{e}^{-0.14 B}
$$

There are two main reasons why the land is unexploited: 1 - low agricultural value of land, inappropriate farming structure and bad situation of land plots; 2 defects in subsurface drainage network. The first reason pertains to 92.2, the second - to $7.8 \%$ cases. On productive soils farmers are looking for ways how to repair drainage network and do not care about derelict lands (BASTIENE, 2002).

The important factor is the drainage system lifetime. The results of research on that issue are presented in Fig. 4.

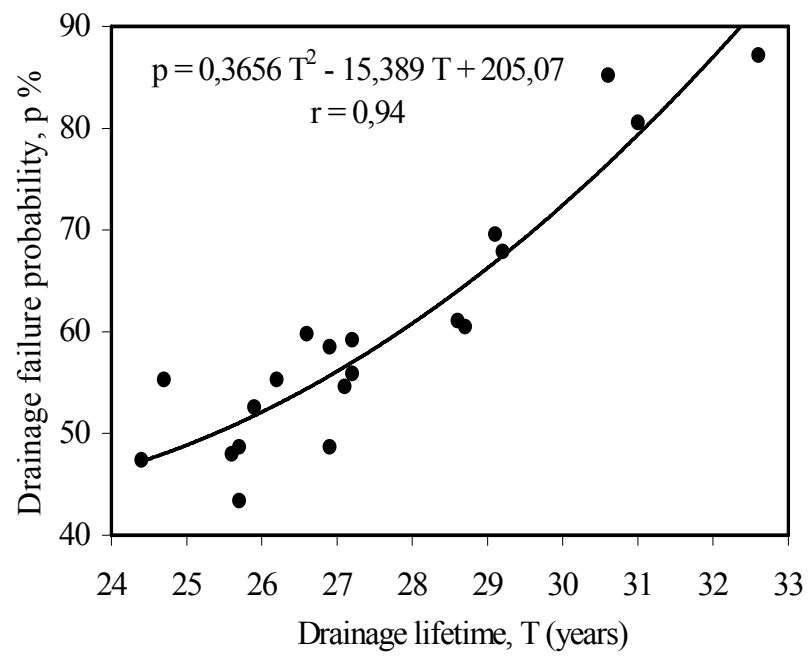

Fig. 4. Dependence of drainage failure probability on the drainage lifetime in Kretinga district

The distribution of the subsurface drainage in Lithuania according to its lifetime is presented in Table 2.

When evaluating the expediency of the renovation of non-functioning and badly functioning drainage systems or refusing their further exploitation, different economical, technical, ecological and social criteria are to be considered.

Economic criteria depend on the market of agricultural products and costs of agricultural production process. When a part of drainage system operation works is financed by the state, the priorities of local agricultural policy are to be taken into consideration: where the land tillage is most expedient, where pastures would be most suitable, where forests should be cultivated. This decision is particularly influenced by potential soil fertility.

When estimating it from the technical point of view, general condition of a drainage system and the extent of its failures are to be considered. The condition of draining network and diversion channels is to be evaluated and possible risks of 
Table 2. The distribution of subsurface drainage depending on its lifetime

\begin{tabular}{c|c|c|c|c}
\hline $\begin{array}{c}\text { Construction } \\
\text { period }\end{array}$ & $\begin{array}{c}\text { Drained area } \\
\text { ha }\end{array}$ & $\begin{array}{c}\text { Lifetime } \\
\text { years }\end{array}$ & $\begin{array}{c}\text { Drained area } \\
\text { ha }\end{array}$ & $\%$ \\
\hline $1940-1945$ & 740 & more then 50 & 884 & 0.03 \\
$1946-1950$ & 144 & & & \\
$1951-1955$ & 15608 & $40-50$ & 172145 & 6.41 \\
$1956-1960$ & 15637 & & & \\
$1961-1965$ & 333938 & $30-40$ & & \\
$1966-1970$ & 537938 & & 1137846 & \\
$1971-1975$ & 650103 & $20-30$ & & \\
$1976-1980$ & 487742 & & 467347 & \\
$1981-1985$ & 285456 & $10-20$ & & \\
$1986-1990$ & 181891 & & 35697 & \\
$1991-1995$ & 33044 & up to 10 & & \\
$1996-2000$ & 2653 & & & \\
Total & 2685794 & & & \\
\hline
\end{tabular}

failures are to be estimated (whether the systems are arranged in quicksand, dust or ferrous soils, settled peat soils or springy areas).

Ecological criteria evaluate the ecological situation in the region: whether the lands of ecological use are sufficient and the conditions for the development of biodiversity are suitable. The expediency of drained lands with low productivity, re-naturalization of valleys of regulated streams and expansion of channel slope zones during the formation of protective profile of a channel are the issues of top priority.

When estimating possible advantages from the social point of view, it should be kept in mind that non-functioning drainage system is not the same as nondrained land area that existed before. If land productivity point increases by 20 and more (depending on the soil type) after draining, this does not mean that drainage system failures will result in decreased land productivity by exactly the same point. In most cases the area of non-functioning drainage system will become boggy and the development of farming activities will not be possible there. However, the ecological situation of the region will improve. Therefore, when estimating the expediency of the renovation of non-functioning or badly functioning drainage systems, social criteria are to be considered: if a farmer possessing a 100-ha farm looses 1 ha due to drainage failures, he looses $1 \%$ of his total arable land area, while a farmer possessing a $2-3$-ha farm looses even a half of his arable land area.

As it is stated in the regulations of the program of agricultural and rural development strategy, changes in land reclamation infrastructure should be accompanied by the means creating suitable preconditions for rational, nature-sustainable re- 
gional agricultural specialization. If the value of state-owned land reclamation facilities changes, the order of financing land reclamation works should change accordingly. Now, four principal scenarios of the allocation of special state budget subsidies are suggested:

I. Special state budget subsidies for land reclamation are allocated with respect to the residual value and the degree of deterioration of land reclamation facilities owned by the state by property rights (base financing).

II. Base financing is corrected according to the increase in land productivity points due to land draining.

III. Base financing is corrected according to the area of derelict land plots in municipalities.

IV. Base financing is corrected according to both criteria (i.e. increase in land productivity points due to land draining and area of derelict land plots in municipalities).

Based on analytical results, special state budget subsidies for the exploitation of land reclamation constructions are suggested to be allocated considering the residual value of state-owned land reclamation constructions in districts (base financing); the subsidies are to be corrected with respect to the increase in land productivity points due to land draining and to area of derelict land plots in districts (scenario IV).

When modelling scenario IV of base financing corrections, both factors are equally estimated giving no priority to any of them. For example, in a group of districts where draining process is less important the financing index is 0.65 according to scenario II; when the area of derelict land reaches $10 \%$, base financing index is 0.42 according to scenario III. According to scenario IV base financing index would be 0.54 there. If the area of derelict land plots makes up only $2.5 \%$, base financing index would be 1.14 according to scenario III and 0.89 according to scenario IV. Figure 5 presents base financing index for districts where scenario IV of base financing corrections was modelled with respect to the area of derelict land plots in municipalities in 2003 (50\% due to the increase in land productivity points, $50 \%$ according to the area of derelict land plots).

\section{INVESTMENT OPPORTUNITIES FROM THE EU SUPPORT FUNDS}

The EU SAPARD programme that started in 2000 addressed many issues related to the modernisation of farm holdings, improvement of engineering infrastructure connected to farming and to the development of alternative activities in rural areas. Private farmers, agricultural companies and co-operative farms have been encouraged to invest in agricultural holdings in order to improve their competitiveness and compliancy with the EU requirements. At the same time farmers were requested to promote farming in harmony with the environment as required 


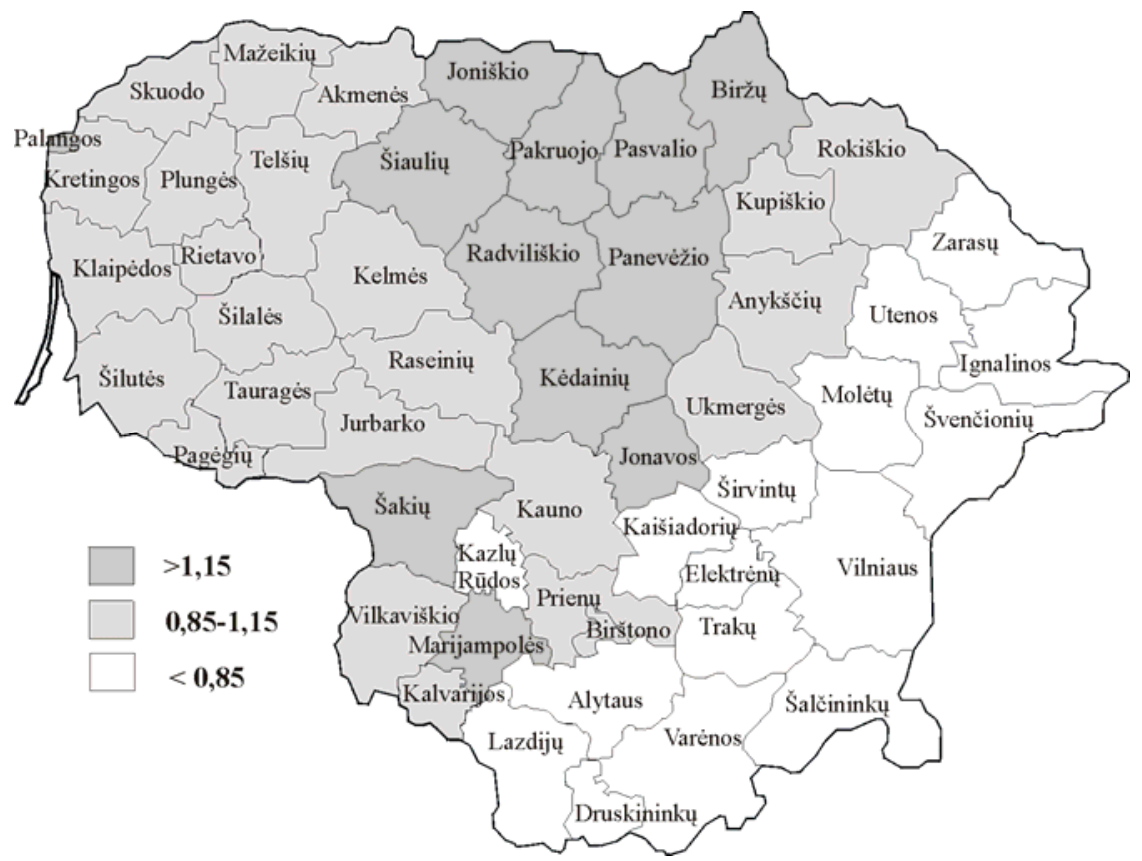

Fig. 5. Regional distribution of base financing index when modelling calculation variant IV

by the new European Agricultural Policy. By the data of the National Paying Agency more than 400 projects granted up to $50 \%$ support for the investments (Tab. 3).

Table 3. Support of investment into agricultural holdings by SAPARD (December, 2004)

\begin{tabular}{l|c|c|c|c}
\hline \multirow{2}{*}{$\begin{array}{c}\text { Regional } \\
\text { administrations }\end{array}$} & \multicolumn{2}{c|}{ Applications received } & \multicolumn{2}{c}{ Signed support agreements } \\
\cline { 2 - 5 } & number & $\begin{array}{c}\text { amount } \\
\text { thousand Lt }\end{array}$ & number & $\begin{array}{c}\text { amount } \\
\text { thousand Lt }\end{array}$ \\
\hline Alytus & 16 & 9.693 & 11 & 4.933 \\
Kaunas & 118 & 68.056 & 100 & 53.585 \\
Klaipėda & 36 & 25.208 & 28 & 19.360 \\
Marijampolè & 86 & 46.514 & 75 & 39.076 \\
Panevèžys & 116 & 60.183 & 90 & 44.963 \\
Šiauliai & 112 & 57.108 & 91 & 42.807 \\
Tauragė & 31 & 16.703 & 20 & 10.875 \\
Telšiai & 19 & 11.142 & 12 & 6.014 \\
Utena & 15 & 6.547 & 8 & 3.958 \\
Vilnius & 29 & 22.280 & 17 & 12.276 \\
Total & 578 & 323.433 & 452 & 237.847 \\
\hline
\end{tabular}


Taking all positive impact of above measures on farm investments, the SAPARD programme provided no support for improving drainage in rural infrastructure.

Drainage pipes as part of complex drainage systems should be considered as belonging to the agricultural land and cannot be treated separately. This private status of drainage in a farm was approved by the new Law on Land Reclamation in 2004. By the law, individual farmers are expected to finance the investments in the drainage which belongs to them. They are eligible to receive some support from the State or European funds. The drainage infrastructure commonly used or serving land plots still belonging to the State is to be financed by the group of users and the State.

Up to now very limited support was provided by the State to individual farmers. The support for drainage to farmers was unavailable from SAPARD.

The water management infrastructure of public interest or of common use has been supported from SAPARD programme. The support included the renovation of polders, water supply and sewerage systems in rural settlements as well as installation or modernisation of artesian boreholes. The National Paying Agency under the Ministry of Agriculture responsible for the administration of support to the rural sector has already provided support to more than 167 projects submitted by municipalities or groups of beneficiaries for the water supply or wastewater handling facilities in rural settlements (Tab. 4). The statistics shows that none of those projects dealt with the proper drainage infrastructure.

Table 4. Support of investments into water management systems by SAPARD (December, 2004)

\begin{tabular}{l|c|c|c|c}
\hline \multirow{2}{*}{$\begin{array}{c}\text { Regional } \\
\text { administrations }\end{array}$} & \multicolumn{2}{c|}{ Applications received } & \multicolumn{2}{c}{ Signed support agreements } \\
\cline { 2 - 5 } & number & $\begin{array}{c}\text { amount } \\
\text { thousand Litas }\end{array}$ & number & $\begin{array}{c}\text { amount } \\
\text { thousand Litas }\end{array}$ \\
\hline Alytus & 21 & 12.476 & 13 & 6.724 \\
Kaunas & 57 & 38.453 & 30 & 17.477 \\
Klaipèda & 27 & 15.968 & 12 & 7.191 \\
Marijampolé & 17 & 8.750 & 10 & 5.621 \\
Panevéžys & 37 & 26.635 & 28 & 18.667 \\
Šiauliai & 25 & 12.185 & 17 & 8.197 \\
Tauragè & 25 & 12.763 & 18 & 7.333 \\
Telšiai & 32 & 23.944 & 13 & 9.155 \\
Utena & 16 & 6.130 & 7 & 2.925 \\
Vilnius & 28 & 14.869 & 19 & 8.535 \\
Total & 285 & 172.172 & 167 & 91.828 \\
\hline
\end{tabular}

In preparing the draft Single Programming Document (SPD) for the use of EU structural funds in 2004-2006 (Ministry of Finance, Republic of Lithuania, 2004) 
the authors of this article have suggested paying much more attention to the water management issues and, specifically, rehabilitation of drainage infrastructure. The measure of "Investment in agricultural holdings" established on the basis of the Council Regulation (EC) No 1260/1999EU on Structural funds (European Council.., 1999a) and Council Regulation (EC) No 1257/1999 (European Council..., $1999 \mathrm{~b}$ ) includes now the possibility of supporting private drainage or irrigation (construction or rehabilitation) projects submitted by farmers. These projects may grant from 50 to $65 \%$ support. The larger support level is awarded to young farmers and to those farming in less favoured areas.

In the sub-measure "Agricultural water resources management" of the SPD prepared for the 2004-2006 much more attention is paid to the rehabilitation of drainage infrastructure. The emphasis will be given to investing in larger drainage systems of common use, systems of canals conveying water and hydraulic structures. The projects for these systems are considered as non-revenue generating projects and are supported at a higher rate $(90 \%)$ with the ceiling of 500 thousand Euro per project ( 1 EUR is equivalent to $3.4528 \mathrm{Lt}$ ). This involves investments aimed at improving technical status of systems or new construction. The usual maintenance interventions are excluded from support under this measure and remain the responsibility of beneficiaries.

In providing support for water management some wider objectives should be achieved:

- safeguarding good state of surface water within the drainage systems;

- reducing risks of unfavourable water regime;

- improving common ecological conditions in rural areas;

- improving ecological value of social (living) and recreational conditions in rural areas.

All projects should comply with the Community environmental standards when its implementation is completed. A prior assessment from environmental national authorities must be submitted.

PONDS

276 ponds were built mainly for irrigation of 30 thousand hectares of land. In new conditions of farming the large irrigation systems were not acceptable for farmers for many reasons and with time they were desolated. Today the plots under irrigation occupy only 4.5 thousand hectares. Beside ponds mentioned, few hundred small ponds were built by former collective farms.

The state (local municipalities) is responsible for ponds maintenance.

Today nobody thinks about ponds destruction. These structures serve for landscape enrichment and recreation, also as wetlands. At larger ponds the hydroelectric power stations are built. 
The big problem is the maintenance of pond structures because most of them serve for more than 40 years. In order to evaluate the situation and to predict consequences a study was undertaken by scientists of the Lithuanian University of Agriculture (DAMULEVIČIUS et al., 1999).

Regarding water amount in the pond and the pressure of water column at the dam 617 ponds belong to the category of potentially dangerous structures (Potecialiai..., 1998). For such a case the Ministry of Environment approved rules on the management and maintenance of these ponds (Tvenkinių..., 1995).

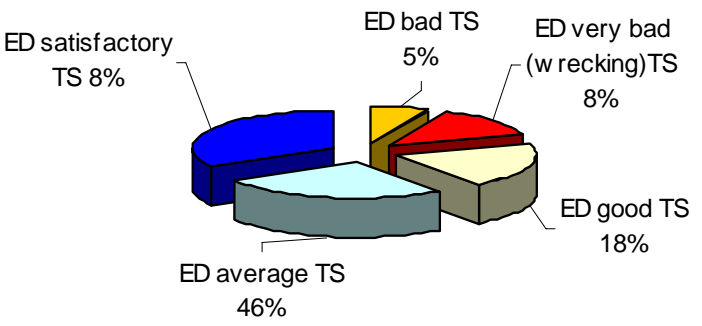

Fig. 6. The technical state (TS) of the earth dams (ED)

\section{SUMMARY AND CONCLUSIONS}

Complicated situation in land reclamation sector in Lithuania is a result of rapid changes. The first aim was the land reform. The land was returned to former owners but for a long time there was no solution about drainage and irrigation systems existing on that land. Farmers were not ready for these systems management and hoped that financing will not be changed. At last the principle decision was made. The main task for the near future is to prepare legal base for normal functioning of drainage systems according to agricultural and environmental requirements.

\section{REFERENCES}

1. Valstybès finansinès paramos, teikiamos melioruotos žemès savininkams melioracijos statinių statybos, rekonstravimo, remonto ir priežiūros darbams atlikti, taisyklès, 2004. LR žemès ūkio ministro 2004 m. rugpjūčio 13 d. issakymas 3D-481. Valstybès žinios 81-2895.

2. BuOŽIS V., BASTIENE N., 1998. Drenažo sistemų eksploatavimo efektyvumo tyrimai. Vandens ūkio inžinerija, 5(27): 66-79.

3. BRUSOKAITĖ-STRAVINSKIENĖ V., 2002. Ariamosios žemès naudojimo pokyčiai Vidurio Lietuvos rajonuose. Vandens ūkio inžinerija, 21(43): 80-84.

4. BASTIENE N., 2002. The main problems of drainage systems exploitation in Lithuania. International scientific conference "Research for rural development 2002". Jelgava, Latvia, 22-24 May, 2002: 133-139. 
5. European Council, 1999a. Council Regulation (EC) No 1260/1999. O. J. Eur. Comm. L161/80, 26.6.1999.

6. European Council, 1999b. Council Regulation (EC) No 1257/1999. O. J. Eur. Comm. L160/80, 26.6.1999.

7. Damulevičius V., Rimkus Z., VaišnORAS A., VyČIUS J., 1999. Lietuvos hidrotechnikos statiniu techninè būklè. Statyba ir architektūra, 9: 61-64.

8. Potencialiai pavojingu hidrotechnikos statinių techninès būklès laikinoji instrukcija, patvirtinta Hidrografinio tinklo tarnybos viršininko, 1998. 1113 įsakymas 52, K: 20.

\section{STRESZCZENIE}

\section{Ekonomiczne motywowanie sektora melioracyjnego na Litwie}

Słowa kluczowe: inwestycje, motywowanie ekonomiczne, systemy odwadniajace, zarzadzanie

W pracy przedstawiono krytyczną ocenę istniejących systemów odwadniających w aspekcie prawnym, ekonomicznym, środowiskowym i technicznym. Około $80 \%$ gruntów rolnych na Litwie odwadnianych przez podziemne systemy drenarskie zajmuje powierzchnię $3 \mathrm{mln}$ ha. Znakomita większość wielkoobszarowych systemów drenarskich o złożonej strukturze technicznej, obejmującej rowy, dreny, kolektory, lokalne drogi, mosty i skrzyżowania dróg, nasypy, zapory, zbiorniki wodne i stacje pomp odwadniających i nawadniających, wymaga dziś - wobec nowej sytuacji gospodarczej - wydajnych sposobów zarządzania.

Przeprowadzono szczegółową analizę instrumentów prawnych i ekonomicznych zastosowanych w przenoszeniu odpowiedzialności za systemy odwadniające na użytkowników. Badania dostarczyły praktycznych przesłanek do zmiany ustawy o melioracji na Litwie i do ustanowienia systemu wskaźników, które pozwoliłyby zracjonalizować rozdzielanie subsydiów na utrzymanie i usprawnianie systemów odwadniających. Obecnie te subsydia, pochodzące z budżetu państwa, stanowią największą pulę środków inwestycyjnych. Stale rośnie jednak wkład finansowy i rzeczowy użytkowników systemu, podobnie jak kierowanie funduszy strukturalnych na projekty publiczne.

Przedakcesyjny program europejski SAPARD, którego realizacja rozpoczęła się w 2000 r., wspierał pewne inwestycje na obszarach wiejskich. Niestety, program ten nie finansował w odpowiedni sposób infrastruktury drenarskiej. Krytyczny przegląd poprzednio stosowanych środków umożliwił zaproponowanie nowych działań w ramach obecnego wsparcia z europejskich funduszy strukturalnych.

Reviewers:

Dr. Józef Lipiński

Prof. Stanistaw Łojewski 